\title{
News Items
}

\section{Circle of Human Systems Management}

\begin{abstract}
Attention HSM circle members!
We have again been able to secure a rather attractive subscription price for a volume of HSM for all circle members in good standing. As you know the institutional price of HSM is about $\$ 71$ while the personal price is about $\$ 37$. The HSM Circle members are entitled to a yearly subscription price of $\$ 20$, including postage and handling!
\end{abstract}

How to join HSM Circle and maintain good standing?

One can join the Circle upon the payment of $\$ 15$ yearly fee and upon filling out a special membership form obtainable from HSM Policy Coordinator. This fee entitles a member to receive the "Co-Enzyme", an internal communicator of the Circle, and to maintain the membership. Part of the fee is set aside for preparing the First Conference on Human Systems Management.

Important! Both the membership fee of $\$ 15$ and the subscription of $\$ 20$ must be forwarded directly to HSM Policy Coordinator, not to North-Holland Publishing Company. The address: Dr. Milan Zeleny, HSM Policy Coordinator, 560 Riverside Drive, Apartment 13-C, New York, NY 10027, U.S.A. (Payments should be made in US \$ only.)

For the current listing of HSM Circle membership please refer to HSM 1 (1), pp. 102-103 and the supplement per December 1980 (see below).

HSM Circle membership:

Supplement per December 1980

Aquila, Louis E., Geln Ellyn, IL (U.S.A.)

Andersson, Haakam, Karlstad (Sweden)

Baetz, Mary L., Fromkin Van Horn Ltd. (Canada)

Bartee, Edwin M., Vanderbilt University (U.S.A.)

North-Holland Publishing Company

Human Systems Management 2 (1981) 131-133

\section{HSM Circle members subscription order}

I am a Circle member and would like to take advantage of the special membership price. Enclosed is:

$\square \$ 15$ to cover by membership fee for 1981

$\square$ \ 20 to cover the volume subscription to HSM Journal

I am not a member of the HSM Circle but would like to join. I have checked the appropriate box(es) above and enclosed the corresponding payments. Please send:

$\square$ HSM Circle membership form

$\square$ Any available past issues of "Co-Enzyme"

Name

Correspondence address

Make checks payable to HSM - M. Zeleny and send the payment and this form to: Dr. M. Zeleny, HSM Policy Coordinator, 560 Riverside Drive, Apartment 13-C, New York, NY 10027 , U.S.A.

Buchstaller, Walter, Vienna (Austria)

Clement, Bill J., Western Washington University (U.S.A.)

Collopy, Fred, University of Pennsylvania (U.S.A.)

Dixon, J.C., Rapidata Inc. (U.S.A.)

Doubel, Palmer, Ardooie (Belgium)

Fabian, Robert J., Hickling-Johnston Ltd. (Canada)

Feather, Frank, Toronto (Canada)

Flamholtz, Eric G., U.C.L.A. (U.S.A.)

Franz, Charles R., University of South Carolina (U.S.A.)

Gharajedaghi, Jamshild, University of Pennsylvania (U.S.A.)

Graham, Robert J., University of Pennsylvania (U.S.A.)

Gray, William, Newton Center (U.S.A.)

Halstead, Edward G., Chicago (U.S.A.)

Henry, Thomas F., Ludwigsburg (West Germany)

Hines, George H., Massey University (New Zealand)

Holtier, Senino E., Polytechnic Institute Iasi (Romania)

Huff, Anne S., University of Illinois (U.S.A.)

Jackson, William L., Action Research Associates (U.S.A.)

Joy, Arthur C., University of Illinois (U.S.A.)

Kanof, Pedro R., Alfa Romeo S.P.A. (Italy) 
Krishnayya, Jaswant G., Systems Research Institute (India) Kruisinga, J.D.M., The Hague (Holland) Kyriazis, Harry C., Panotex S.A. (Greece)

Lewis, Ralph G., Florida International University (U.S.A.)

Raduchel, William J., Data Resources Inc (U.S.A.)
Rychetnik, Ludek P., University of Reading (England) Sandkull, Bengt, University of Linköping (Sweden) Skolka, Jiri, V., Institute for Economic Research (Austria) Suga, Nelson, Curitibas (Brasil)

Vallée, Robert, University of Paris (France)

\section{Conference on 'Model Realism'}

A working conference on Model Realism is to be held in April 1982 near Bonn/W. Germany. It will deal with the modeling characteristics of different methodologies and is intended to be a first step in an ongoing comparative discussion of the extent to which these methodologies can be used or combined in order to contribute to solutions of real world problems. A relevant question is whether these methodological approaches model key phenomena and aspects of the real world systems adequately; e.g., how do they keep track of uncertainty in observations, of concurrency of events, of a (partial) autonomy, or of a multifunctionality of system components.

In order to promote a coherent and reliable discussion, a set of problems (Call for Papers is available on request) has been formulated, each from a different background. A set of questions common to all problems is also given. Papers will be solicited from people asked to answer as many of these questions as possible.

There will be no parallel sessions. The submitted papers will be analyzed (after the evaluation by the program committee) by respondents who are not closely identified with the particular methodology in question. The analysis should provide some insights both into the range and strength of a given methodology and into its limitations and weaknesses.

Due to the requirements of paper evaluation procedure, the deadline for full-draft versions cannot be later than October 20, 1981. It is planned that the proceedings of the conference will form the basis of a book to be published by Academic Press.

This book should document the state-of-the-art of contemporary systems modeling and design methodologies, and point out the problems and gaps in current approaches. For further information write to:

\author{
Horst Wedde \\ Gesellschaft für Mathematik \\ und Datenverarbeitung mbH Bonn \\ Postfach 1240 \\ D-5205 St. Augustin 1 \\ W. Germany
}

\section{Computerization and Social Research}

The impact of computerization on social research is the main topic of a Conference to be held at the Université des Sciences Socialies, Grenoble, France, 14-18 September 1981. Among the conference themes are:

- New Types of Research (complex data, computer mapping, aggregation and disaggregation)

- New Institutions (data banks, long-term storage, machinereadable data banks);
- New Tools (networks, mini-computers, artificial intelligence, compatibility and translation);

- Relations between Data Producers and Users (anonymization of data, public opinion polls, government and commercial data);

- Social Science Teaching (statistical packages, summer schools of statistics and computing, data services and technological development). 
One-day workshops include:

(1) The Assay/Evaluation of Survey, Ecological, Satellite, and Cartographic data;

(2) The Organization and Management of Data Services;

(3) The Formation of a Professional Data Archivist and Librarian.

For more information about the conference or the workshops write to:
Ms. Alice Robbin

IASSIST President

Data and Program Library Service

4452 Social Science Bldg.

University of Wisconsin

Madison, WI 53706

U.S.A. 